\title{
A Tale of Two Kewangs: A comparative study of traditional institutions and their effect on conservation in Maluku
}

\author{
Karno B Batiran ${ }^{1, *}$ and Ishak Salim ${ }^{1,2}$ \\ 1 Peasant School Network of PAYO-PAYO. Maros, South Sulawesi, Indonesia. \\ 2 Universitas Teknologi Sulawesi, Political Science Department, Makassar, Indonesia \\ * Corresponding author: karnobatiran@payopayo.or.id
}

\begin{abstract}
This study explains how kewang, a traditional institution that deals with social affairs and natural resource management, maintains traditional ecological knowledge and practices in Maluku. This study focuses on two comparative villages (negeri): Haruku and South Buano. The study adopts a historically situated new institutionalism approach to analyzing the dynamic developments of kewang and how it affects community members in the context of conservation and natural resource management of the petuanan customary areas of the two negeri. By examining institutional change including history, ideology, organization and authority of kewang with other institutional forms such as soa, government, church, and NGOs the study shows the path-dependence of the two respective kewangs. In Haruku, the kewang has long stayed intact because the institution is still practiced as a cultural principle, maintaining itself through the tradition-based leadership succession mechanisms and by continuing to carry out its functions, as well as pursuing innovations within kewang education for future generations. In South Buano however, due to the long absence of a kewang, efforts at revival show the strong influence of rational choice thinking principles, dependent on the formal authority of the negeri government. The study concludes that historical junctures shape the role and authority of kewangs in performing natural resource functions, and which can have longnstanding generational impacts on conservation possibilities. Meanwhile, kewang also rely on both its continued endogenous acceptance among local community members, and depend on its relations with other key institutions in society.
\end{abstract}

Keywords: adat and customary law; conservation; community based natural resource management; traditional ecological knowledge; new institutionalism; kewang; sasi; Maluku; Indonesia; Wallacea; Village Law

\section{Introduction}

Village governance and customary institutions have undergone a remarkable change in Indonesia, with origins that reach back long before the establishment of the Indonesian state, and subsequently undergoing a series of changes since independence. The first modern wave came with the onset of Western religion in the $15^{\text {th }}$ century, in which Islam and Christianity layered onto and shifted old traditional beliefs and practices, particularly in the spice rich regions among the people of Maluku. The Dutch and British challenged each other's primacy to this resource frontier, which eventually gave way to the establishment of the Dutch colonial periods and its evolving administrative systems (Cultural Research team of Maluku Province, 1976). Indonesia's independence, and Maluku's incorporation into the nation-state was institutionally defined by the longstanding authoritarian rule of the 'New Order' (1966-1998), which established a uniform system of Javanese-style ${ }^{1}$ regional and village governments. Incorporation into the village government system removed various customs but also converged with the diverse governance mechanisms and systems of authority, particularly in relation to natural resources. Culturally, Zakaria (2000) describes

\footnotetext{
${ }^{1}$ Law number 5 of 1974 on Pokok-Pokok Pemerintahan di Daerah, and Law number 5 of 1979 on Pemerintahan Desa. 
this period as the New Order's attempt to destroy the structure traditional knowledge, while nationalizing resources for the benefit of the state.

The reformasi period that marked the end of the New order regime largely left intact politicoadministrative relations, with an important discursive shift that management authority was to be democratically decentralized to the regions. Nevertheless, many of the existing patronage systems and formal governance relations remained in place in rural and remote areas, but which further experienced another legal change with the onset of the Village Law No 6/2014 (Vel and Bedner, 2015). This law includes new forms of autonomy at the village level, which are having a tremendous impact on budgets and political systems throughout the region (Antlov, 2003, Aspinall and Rohman, 2017). One of the cultural dimensions of these impacts involve a discursive shift that invoke new initiatives to empower and revive traditional forms of authority and remapping them back into the state systems (Sasmitha, 2020). This research examines how traditional institutions in two villages responded to these changes, and connects them with the overall institutional dimensions relative to conservation of natural resources.

Across Indonesia, the role of traditional communities in environmental conservation and natural resource management in certain customary areas (ulayat) still plays an important role. In Maluku, for example, most villages (negeri) such as those in the Lease, Seram and Kei Islands are acknowledged to be intimately linked to conservation management systems (Novaczek et al., 2001; See also Zerner, 1994). Their mechanisms are pursued through kewang, a customary instrument/institution that negotiates the governance of social affairs and natural resource management. Kewang and other traditional organizations such as the Raja (head of negeri), Soa (alliance of clans in one negeri), Dati (head of clan), Kapitan (head of negeri security), Marinyo (information disseminator), and Tuan tanah (clan leader) are part of local governance system based on local ideology, knowledge and rules which have been collectively agreed on for generations. Sasi ${ }^{2}$ or prohibition on carrying out certain activities in the petuanan ${ }^{3}$ area, together with the sanctions enforced by kewang-as guardians of petuanan-against violators, constitutes a form of a broad set of interlinked traditional institutions. It is the rules of the negeri, part of the vow of the ancestors (ina $a m a$ ), which are then maintained continuously to become the norms, values and practices among community life.

\subsection{The case study context and a historical new-institutionalism approach}

This case study adopts a new institutionalism approach, specifically 'historical newinstitutionalism,' by examining the internal and external factors affecting individuals who organize themselves into certain organizations in the process of conserving and managing natural resources. This study focuses on two kewangs, in Negeri Haruku (Haruku Island Sub-district, Maluku Tengah District) and Negeri South Buano (Huamual Belakang Sub-district, Seram Barat District). In the Maluku tradition, the membership structure of the kewang comes from the representation of every soa in one negeri. Traditionally, both in South Buano and Haruku, the selection and the appointment of the soa representatives to be the members of the kewang are regulated based on hereditary clans. The elected members of kewang will protect natural resources in the petuanan (areas within the customary rights of the village).

The political and ecological contexts drive this research. In the political context, the existence of traditional institutions in Maluku until today demonstrates community resilience to external

\footnotetext{
2 Sasi is sets of rules which regulate resource use and social behavior. It also means an indigenous fisheries resource conservation and management tradition in Maluku. sasi has a long history and has undergone transformation through time. "Sasi is an encompassing body of meaningful relations between people, the natural environment and gods, ancestors and spirits" (von Benda-Beckmann et al. 1995 in Irene Novaczek et al. 2001).

${ }^{3}$ In some Maluku communities, control over the land and marine territories (petuanan) and their resources is vested in a social institution that has a code of conduct, rules and regulations.
} 
political forces. No doubt, larger political forces have intervened and changed many aspects in the social life of the Maluku people. However, in the case of the Negeri governance, the traditional government system is still firmly in place. One example of the political forces is central government intervention through contemporary conservation regulations, which also shapes the local political context. The Regulation of the Ministry of Maritime and Fishery No. 17/2008 includes the management policy of Maritime Conservation Areas, which are divided into two types of areas, the Marine Adat Protected Areas ${ }^{4}$ and the Marine Cultural Protected Areas. ${ }^{5}$

In the ecological context, both Buano Island and Haruku Island are now facing threats of natural resources degradation in terrestrial and coastal areas. Without sustainable natural resource management, it will have a direct impact on the destruction of important ecosystems in coastal areas, such as the habitat of endemic birds Kehicap Buano (Black chined monarch, or Symposiachrus boanensis, or Boano monarch), and Gosong Maluku (Eulipoa wallacei), marine mammal passageways, and of course the food provision for the community and fish categorized as ETP (Endangered, Threatened, and Protected) (Abrahamsz, et al., 2015). More specifically, these threats include, first, reduced population of Duyung or Dugong (Dugong Dugon). Second, six to seven species of whales and five species of dolphins inhabiting these waters were found to be affected by plastic waste (Khan et al, 2016). Third, fishery resources from the turtle group are under pressure from slaughter at the beach where they lay eggs, effects fromm turtle eggs harvest, and ladung (hanging spear) fishing gear. Fourth, threats to fishery resources from mollusk groups such as lola (Trochus niloticus), turbo (Turbo marmoratus), and clams are present because of their use for consumption. These ecological contexts can have serious impacts to communities without adequate sustainable management systems.

\section{Methodology}

The study consisted of more than ten in-depth interviews at the two Kewang institutions, three focus group discussions (FGDs) and a literature review. The data collected was analyzed using the historical new institutionalism approach to trace the development of traditional institutions over time in relation to their role in protecting specific areas and species. This approach, in addition to observing the institutional changes, also examines the behavior of its members in formulating the norms and roles of the institutions, as seen in the institution rules, as well as its implementation and impact on the affairs it regulates.

Traditional institutional research using a new institutional approach has previously been carried out by a number of researchers, such as Géraldine Froger and Philippe Méral through their article entitled "Towards an Institutional and Historical Analysis of Environmental Policy in Madagascar" (Froger and Meral, 2012). The authors explore the application of ideas from historical institutionalism about path dependence to the study of environmental policy in Madagascar and then applied the analysis to the "diverging" trajectories of environmental policy in Madagascar during the $20^{\text {th }}$ and $21^{\text {st }}$ centuries.

The new institutional approach has many aspects and variations. The shape and nature of the institution depends on the actor. There is a consensus that the core of political institutions is the 'rules of the game.' The actors and groups fulfill their interests in a collectively limited context (Goodin 2000). These constraints in many ways also benefit individuals or groups in fulfilling their respective interests. The limiting factors of individual and group activities influence the formation

\footnotetext{
${ }^{4}$ These areas include: a) coastal and/or small island areas that have a community with own living customary (adat) law, traditional property rights and adat organizations; b) have customary rule/consensus applied for environmental sustainability (Article 8[1]).

5 These areas include: a) a spot where ship with specific archaeological and historical values had sunk; b) maritime historical sites that has historical, scientific, and cultural value, and need to be protected for conservation and national cultural advancement; c) religious or customary ritual sites. (Article 8 [2])
} 
of preferences and motivation of actors and groups. This restriction has historical roots as a legacy from past actions and choices, which realize, maintain, and provide different opportunities and strengths to each individual and group. To elaborate how the institutional changes in the context of resource management, Ensminger (in Holler 2007: 15) describes four endogenous aspects to be considered in one locus, like the negeri, namely: ideology (world view), institutions (rules of the game), organization (embodiment or organized practice of institutions), and bargaining power. This study describes these aspects by examining how the dynamic changes took place in kewang organizations in the two research sites. In addition, these four aspects are able to provide a comprehensive picture related to the internal dynamics between actors in traditional organizations at the village level and their relationship with the wider political environment in a country such as Indonesia.

In addition, to explain the institutional changes around a kewang organization across time, historical new-institutionalism also utilizes the concept of path-dependence, where change is not necessarily the case when a policy is applied. The organizations aspiring for change through an intervention need to learn from important events in the past (a critical juncture) to understand why the emergent conditions are formed before setting appropriate steps. In this case, it is important to see the changes that occur at the institutional level.

This study answers a number of operational questions in the context of historical newinstitutionalism: (1) What is the historical, political, and knowledge background of traditional institutions, particularly that of the kewang?; (2) How are the internal conditions and institutional dynamics of kewang related to environmental conservation and petuanan natural resource management?; (3) How does the impact of the current operation of the kewang in conservation and petuanan natural resource management? The first question will be answered in section 2 by briefly outlining the history of the Buano and Haruku institutions. The second and third questions will subsequently be addressed by explaining specific aspects of ideology, institutions (rules of the game), organization, and bargaining power in the kewang of South Buano and Haruku. The final section concludes that in Haruku, the existence of kewang is still strong because the customary institution remains a living 'cultural principle' in carrying out ancestral orders, maintaining its continuity through mechanisms of leadership change based on tradition, and still actually performs its functions, as well as developing educational innovations on kewang for future generations. In South Buano, due to the long kewang vacuum, the efforts to revitalize customary institutions and revive kewang organizations demonstrate the strengthening of the 'rational choice thinking' principle that rely on formal authority of the negeri government, which is still weak due to district level regulations.

\section{Traditional Institutions of Haruku and South Buano}

South Buano and Haruku have more or less the same traditional institutions. Both employ a government system called the negeri which is different from the formal village government system. A raja (leader of the negeri), also known as bapa raja (village head), ${ }^{6}$ is the community leader of all clans in one negeri. The communities in one negeri are divided based on soa and clan. Soa is a group of community members based on kinship line, which consists of several clans. Each soa has a head of soa, and each clan has a head dati or pati. ${ }^{7}$

\footnotetext{
${ }^{6}$ Before adopting the term negeri, widely used in other Maluku coastal areas, there is a local term for each region. Before the original inhabitants lived in the coastal areas, the Haruku people used the term 'Aman' to refer to village. While, for South Buano people, before they inhabited the coastal area and while still living in the hills, they called the village as hena. The transition of the term into negeri might occurred when the Portuguese and the Dutch began to come to control the Maluku islands.

7 In Haruku, there are clans who have the right to occupy certain positions. The raja position comes from the Ferdinandus clan, the land kewang from Kissya clan, sea kewang from Ririmasse clan, the kapitang position from Latuharhari clan and
} 
A head of soa maintains family relations between clans and between certain clan families and families of other clans in one soa. The coordination between the head of soa and the clans are carried out through the heads of dati (clan head). The heads of dati uphold the customary inheritance of each clan, in the form of a clan traditional house. The kinship in one soa is marked and bound by the presence of the traditional or heritage house which represents the existence of a clan in a negeri.

Hierarchically, in the negeri customary government structure, although raja is the highest leader in the negeri, raja does not have the authority to regulate the clans of each soa, and the head of the soa is not subordinate to the raja. Soa is a politically autonomous clan entity. In addition to the raja, head of soa, and head of Dati, there are customary institutions sub-structures, namely marinyo, kapitan, and kewang. Marinyo was the assistant of raja to disseminate negeri related information to all community members, which was distributed through tabaos, a direct delivery method by shouting and going around the village. Currently the tabaos have been gradually replaced by written correspondence and cellular phones. Kapitan is the warlord responsible for the security of the negeri. When any conflict between villages occurs, the kapitan will be in charge of handling protection and security affairs.

The customary position which oversees the village's natural resources, both in the forest area (ewang) and in the coastal and marine areas is kewang. The protected area is known as the petuanan, a customary right area of the negeri, where prohibition terms called sasi apply. The kewang corps has a monitoring and conflict management mechanism. If someone, from that negeri or from outside is caught violating the sasi in the petuanan area, the kewang will hold a hearing and decide sanctions.

Every soa in South Buano and Haruku have members of kewang led by a chief of kewang, who is in charge of protecting both the forest and sea. In South Buano, the kewang has 8 members or two members from each soa, while in Haruku it has 8 kewangs from each soa so they 40 members in total.

\section{Kewang of Haruku and South Buano: Its survival and revival}

Eliza Kissya (age 70) is the head of the fifth kewang in Haruku. He was assigned as head kewang by Kissya clan (a clan entitled to the position of kewang leader) in 1979, when he was 31 years old. The forty members of Haruku's kewang came from 5 soa (Soa Raja, Suneth, Moni, Lesirohi, and Rumalesi). He and his members guard the entire territory of the Haruku's petuanan, both on the mountain (land) and at the sea. One achievement of Haruku's kewang is to protect the marine environment by maintaining the tradition of 'closing' and 'opening' the annual sasi for Lompa fish. His consistency and firmness as kewang in enforcing the sasi related customary rules led the Ministry of Environment to grant him the Kalpataru award in $1985 .{ }^{8}$

Between 1992 to 1997, the kewang experienced difficult challenges when PT Antam secured state permits for gold mining exploration and planned continued exploitation of upstream areas of the Learisa Kayeli River. This river is part of the Haruku's petuanan area and is prohibited from any activities that will destroy the natural environment along the river banks and the estuary. PT Antam was a lage company with foreign investment and had strong backing from the central government.

Kewang Haruku together with young people of the Negeri made a strong push for refusal to PT Antam. Challenges to operations were undertaken, such as disturbing workers and damaging signs

tuan tanah (leader) is from Hendatu clan. As for the position of soa chiefs are successively Soa Raja from is Ferdinandus, Suneth from Souissa, Moni from Sitanija, Lesihori from Talabessy, and Rumalase (also called free soa) from Ferdinandus. The position of marinyo can come from any clan and not based on heredity.

8 In addition to the Kalpataru award for his environmental service over Negeri Haruku, several other awards he received were Satya Lencana (1999), Coastal Award (2010) and as inspirational figure in disaster management (2012), and other awards from various institutions. 
of prohibition for residents deliberately made by the company in the exploration area. According to Eliza Kissya, besides the fact that the area was their traditionally protected petuanan territory, the river estuary was also habitat for Lompa fish to lay eggs every year. If the river flow was polluted, the river habitat would be damaged and would have a direct livelihood impact on Haruku people. As a result of changes taking place in the river allegedly due to mining activity, kewang failed to perform opening the sasi ritual the following year.

In this struggle, the kewang were facing fierce pressure, especially to Elisya Kissya, who was labeled "Anti-Development" by certain parties in Maluku who were favorable toward the company. However, this did not make the kewang and Haruku customary community afraid. They also began too ally with external advocates, strengthenning their alliances with indigenous peoples movements, gaining support from the Baileo Foundation that built a network of NGOs, academics and organizations advocating for the rights of indigenous peoples in Jakarta (such as the Telapak Association) and the National Commission on Indigenous Peoples Rights. With the alliance and the daily resistance carried out by the kewang and Haruku citizens-including the kewang kecil (the young generation of kewang), they finally succeeded in stopping PT Antam's operations and all of the company's equipment was displaced from the Learisa Kayeli estuary area.

Since then, the Kewang of Haruku continues to carry out its traditional functions as a guardian of the sea and mountains by relying on traditional ecological knowledge. They also carry out a number of conservation activities in the petuanan areas and routinely organize the sasi ceremony to harvest Lompa fish. Through this Haruku fishery tradition, all residents of Negeri Haruku can take advantage of these results for one year. Until now, Eliza Kissya is still the head of the Kewang and the Kissya clan-as the legitimate successor to the Kewang head, he is preparing transition to the next chief of kewang.

In contrast to Haruku's kewang tradition, in South Buano, a grievous event occurred in 1983, forcing the dismantling of the kewang institution. At that time, the kewang of South Buano caught a fisherman violating the sasi. The Kewang Chief reprimanded the fisherman and tensions escalated. The fisherman was not a resident of South Buano, but from a neighboring village, North Buano. Such a violation of sasi law would normally be processed according to customary law and perpetrators given customary sanctions. However, some residents of North Buano were angered and carried out attacks on South Buano. Incident ensued, leading to a murder, vandalism, and arson undertaken at the Baileo Negeri (traditional meeting hall), among traditional houses of four soa, and at homes in South Buano. The riots happened quickly and the people of South Buano fleed to the hills.

The local government and the police mobilized to help rebuild the village, receiving support from beyond the Buano islands. Formal justice proceedings took place in court and some people were found guilty and imprisoned. A few months later, the raja and other customary institutions such as the tuan tanah, kapitan, head of soa and dati of South Buano decided to terminate the kewang institution from guarding the petuanan area and implementing the sasi.

Although the incident took place nearly four decades ago, it still holds much trauma for the people of South Buano ${ }^{9}$-especially among women. Sixteen years after the incident, the Maluku conflict began across 1999, in which similar rioting took place in South Buano. The attack of 'Laskar Sarani' ("The Christian Brigade") from outside Buano Island against North Buano (a predominantly Muslim community) provoked retaliations by the latter toward South Buano (predominantly Christian). The second attack from North Buano residents was considered to be motivated by religious differences.

The cessation of kewang operations in the 1980s and 1990s was followed by increased fishing activities that damages to the environment and reefs on the coast of South Buano. Bombing for

\footnotetext{
${ }^{9}$ According to Sumanto Al Qurtuby in 'Religious Violence and Conciliation in Indonesia: Christians and Muslims (Al Qurtuby, 2016) and Hermien L. Soselisa, the conflict left strong disappointment and regret from a number of North Buano people who recognized the bond as brothers, pela (Soselisa, 2000).
} 
fishing in the coastal regions were common. Almost all fishermen used gear that destroyed habitats and were indifferent to endemic species at that time. Surveillance against these destructive practices were only carried out by the sporadic formal marine patrols. Residents reporting destructive fishing practices often found themselves in a complicated situation as police suspected whistleblower involved among the perpetrators. The destruction of habitat and marine biota continued without much control through the 2010s.

The emergence of awareness to reactivate the new kewang in the two negeris on Buano Island emerged 2014. LPPM from Ambon City facilitated the people of North and South Buano to revitalize customary institutions, especially kewang, to protect coastal and marine resources based on local values shared among the community. This process was intensive and continues to the time of writing as the kewang institution has gained a new image and mandate for carrying out environmental protection tasks, both on land and at sea.

\section{The Endogenous Arena of Kewang}

To examine how kewang preserve the environment and manage natural resources of the petuanan, one needs to examine the endogenous aspects of the traditional village organization. Ensminger's (in Holler 2007: 15) four endogenous aspects of resource management include ideology, institutions (rules of the game), organization, and bargaining power, which are applied to the analysis in this section.

\subsection{Ideology}

The post-independence historical development of governance at the village or negeri level can be divided into three periods, i.e. the customary (before western colonization), state centralism (from late colonization through early state establishment), and regional autonomy (The reformasi era of democratic decentralization). This periodization is simplified to map the governance changes of the negeri that relies on certain ideologies, namely customary ideology, which was strongly adhered to before the enactment of Law No. 5/1979 on village governance, followed by the ideology of state centralism and uniformity of village governance systems, and subsequently the ideology of regional/village (after the 2014 Village Law).

The Christian influence, spread through Dutch missionaries in Haruku and South Buano remains a core defining identity. Many elements of past values (native Maluku religion) are not always in sync with Christian practice and teachings. Even if there are still activities based on old traditions, such as the practice of opening and closing the sasi, the presence of the church through the pastor is required. This can be seen in the practice of closing and opening sasi in Negeri Haruku. It means, the role of sasi is no longer only done by Kewang and raja, but also incorporating Chrristian elements. Another practice in which the church also participates in the genuine Maluku tradition is the church sasi. The combination of the words sasi and church shows two values that underlie the practice of 'prohibition,' namely the way of life of indigenous peoples and the church teachings.

Both in South Buano and Haruku, customary practices remain strong however, evident in the tradition of community governance, especially the negeri government (village) where the highest institutional structure is in Saniri (deliberation consisting of all the organizations of the adat) and the persisting governance structure of the negeri namely the raja, soa, dati, kebang, kapitan, and marinyo. In the context of the Indonesian state system, the raja is at once the administrative head of negeri (village head), followed by the hamlet, head of affairs, section head and so on. In South Buano Village, at time of writing the head of negeri is a temporary official extended by the Head of West Seram District's mandate. The implementation of the village head election or the ratification of the raja from the parenta clan as the definitive village head has not been approved by the district government on the grounds that the local regulations related to village government have not been issued. 
In both negeri Haruku and South Buano, Christian influence has been very strong. LPPM Maluku who sought to explore the local knowledge related to the management of petuanan and sasi practices found that worldview as a congregation affected their response to customary institutions, which are not contradictory in the lives of regular citizens. The combination of customary and noncustomary institutions in South Buano occurs between traditional and church-based knowledge. The concept and application of 'church sasi' has been going on for a long time - especially after the kewang conflict in Buano in 1983 - and individual congregations who trusted the church (pastor) to apply sasi in managing their resources abandoned the traditional provisions of sasi they applied previously.

Meanwhile, in Haruku, the practice of church sasi is criticized by the chief of kewang. According to him, it is far better to instill an attitude of honesty in the congregation, rather than carrying out the practice of church sasi. In his logic, people ask for sustenance from God inseparable from nature, stating that "after the provision is given by Him, we ask Him to look after us." It is unclear who supervises and who gives sanctions when someone violates the church sasi. If the customary institutional mechanism is used, then kewang will establish the sasi, guard it and impose sanctions on violators. According to Haruku's head of Kewang, it would be better if the application of sasi, now taken over by the church, can be discussed together between the church and the customary organization. Church sasi has applied for decades, especially in the Sarane villages in which the majority are Christians.

The influence of the ideology of the modern state seems to have had a different effect on the performance of the kewang in those two negeris. In Haruku, the relation between bapa raja as head of negeri with the head of Kewang is less harmonious, so Kewang has not received full support from the village government through the budgeting mechanism to sustain the performance of kewang in Haruku. However, for the head of kewang, the cultural beliefs upholding kewang tradition and membership is a hereditary mandate that cannot be ignored, and makes them relatively independent of the village government. The head of kewang have taken various steps and internal policies to maintain the existence and sustainability of their work to preserve the environment and manage natural resources with traditional ecological knowledge. Therefore, until now the kewang manages to meet the internal needs of the organization while ensuring the livelihood of their family members.

The integration of kewang into South Buano government system has been more challenging. The growing individual values lead some people to perceive membership as a financial opportunity to earn extra income. In Haruku, being a member of kewang is a cultural consequence in which particular clan for generations has been set as the kewang clan, while in South Buano, being a member of kewang is largely financially motivated. The financial incentive is provided through the village government budget sourced from the village funds, where a kewang member is paid Rp $225,000-300,000 /$ month, received every six months. In Haruku, membership is cultural, and the associated work is voluntary.

In Haruku, problems faced by kewang members in protecting resources relative to the need to provide for family members is also a concern. However, at this time solutions are not based on giving financial incentives. One solution pursued by the Haruku's head of Kewang sought support to cover transportation cost of kewang in performing protection tasks, which can be used to go to the sea and fish for members of the kewang. This method is considered more effective given the cultural aspects of revitalizing the kewang as the inherited responsibility from the ancestors and protecting the petuanan. The efforts of kewang are increasingly gaining formal support, such as by the Ministry of Maritime Affairs who provided boats, engines and other fishing gears in 2017.

The description above demonstrates a complex ideological struggle between the church and tradition on one hand, and custom and the state on the other. While customary ideology still thrives in both places, Haruku still more fully adheres to the traditional institutions, owing largely to the 
ongoing functioning of kewang tradition. How exactly the institutions shape the contemporary forms of kewang in these two places will be discussed in the next section.

\subsection{Institutions}

The two cases can conceptually be categorized as two types of traditional institutions that revolve around norms, values, and rules, and its functions in society. These are institutions dealing with human relations, and those relating to the natural environment. The social function of the first institution is to build solid and cohesive kinship relations, while in the second, functions are to build a harmonious relationship between humans and nature to maintain the availability of natural resources to fulfill livelihoods.

In South Buano, the LPPM Maluku assessment (August 2017) indicated that the rules governing the relationship between humans and the environment are demonstrated through community practice to protect certain forests or marine areas from any disturbance or designating them as sacred. This practice is arranged through prohibitions or sasi, enforced by kewang mandated specifically to carry out protection through certain rituals and actions against anyone who violates them. Sasi and kewang are practices that are influenced by norms or values with ecological functions. Through sasi, villagers are aware when they can harvest natural resources, such as eucalyptus oil trees that grow abundantly in the customary forests of the Buano community, or harvest lompa fish in Learisa Kayeli River in Haruku and other high economic value natural resources such as sea cucumbers, lola shellfish, bia-bia and octopus. There is also sasi to protect plants grown by the Buano community. For example, sasi for coconut trees allow for optimal harvest. The practice of sasi thus allows for the sustainable use of natural resources.

When observing the differences in institutions under the customary, state centralism, or regional autonomy regime, the institutions have experienced a number of changes. Under the customary regime, the negeri members were familiar with sasi, masohi (labor exchanges in one negeri), badati (cultural practices to maintain the food security in one negeri) and pasuri or patita (eating together). Under the centralized state, the swatantra system, a formalistic government-style system prevailed. The Javanese idioms were dominant at that time and applied nationally such as desa (village), dusun (hamlet), swadaya (self-help) and gotong-royong (mutual cooperation), as well as others that showed up as a change in institutions. The raja for example, no longer necessarily became the head of the negeri government, but needed to be conducted through a direct election with the control of the state apparatus under formal legal rules. This shift in governance practices had consequences of degrading traditional values, norms and rules in many negeri in Maluku and in general throughout Indonesia (Davidson and Henley, 2007; Muur et al., 2019).

The application of Law No. 5/1979 on village governance and the uniformity of this centralistic system throughout the country reduced the primacy of customary institutions. This law degraded the values behind the practice of sasi, masohi, badati, and numerous others, and ultimately reduced the role of indigenous organizations like the raja and the head of soa, the head of dati, kewang, and especially kapitan and marinyo. On the one hand this structurally weakenened the power of local customary authority, while on the other facilitated outsiders to commit violations, such as exploitative practice on customary land and waters.

The weakening of the kewang roles in South Buano as environmental guardians of the petuanan eventually makes it easier to degrade natural resources without considering their future availability. In contrast, in Haruku, the strengthening of kewang to protect the petuanan has made it difficult for many parties to exploit the natural resources of the negeri, which was strengthened further after the victory against mining claims.

Today, the Indonesian state has recognized indigenous peoples and traditional rights and are further buttressed by the current Village Law. LPPM Maluku brought the knowledge and formal regulations to the indigenous organizations and strives to combine the state's formal andates for 
indigenous peoples institutions. This combination of knowledge/institutions allows for the creation of new rules in conservation and natural resource management of indigenous peoples and strengthens their political positioning.

One ongoing debate of traditional institutions relates to the church. It is undeniable the continued dominance of the church over local values and has contributed to the abandonment of a number of perspectives, norms, and old symbols that were passed down through generations, particularly in Haruku. Therefore, according to Haruku traditional elders, it is necessary for the traditional institutions to sit together, locally known as 'tiga batu tungku' (three stones of the stove). Convesely, in South Buano, the church sasi practice is viewed in a positive light, particularly among youth. According to them, it is precisely because of the church sasi that the younger generation is aware of the existence of sasi. The practice of sasi, however, as part of the knowledge systems that govern natural resources have long been abandoned. Without the role of the church in adopting the old sasi it is unlikely to be recognized by younger people. They disagree about considering the church sasi as an attempt by the church to earn additional income-like tithing. For them, the church sasi depends on the sincerity of the congregation. The church does not specify the amount and instead relies on the norms of Christian teaching to, as one youth stated: "Give the emperor what he has and give to God what He has".

In these two negeri, both the LPPM Maluku in South Buano and the Baileo Foundation in Haruku, are gradually promoting indigenous values to be introduced as rules in formal regulations, particularly in relation to conservation management i.e. Negeri Regulation on Coastal Area Protection. In Haruku and Buano, this effort is at the same time a participatory process of strengthening the customary law while gaining new knowledge.

In Haruku, the head of the kewang established an educational innovation initiative that allows new generations to recognize and practice custom-based knowledge, values, norms and rules through the 'kewang kecil' (kewang youth) program which is also an approach to recruiting future cadres. ${ }^{10}$ Unfortunately, political practices at the district level have prevented the adoption of negeri regulations in various villages in Seram Barat and Maluku Tengah districts, due to the postponement of issuing District Regulations on Negeri Government by the district head (discussed below). According to community members and academics, such neglect demonstrates the reluctance of political elites to strengthen the political autonomy and authority of indigenous peoples and their organizations.

\subsection{Organizations}

The government structure in Buano and Haruku is more or less the same. Yet in South Buano, the current head of negeri government is a temporary official. This arrangement has persisted for years, whereby the district head continues extending temporary official tenure every 6 months. The rationale for postponing elections and approval of a new raja is because a district regulation on Negeri Government has not been issued. The district government considers internal problems in some negeri regarding the 'matarumah' principle in determining which clan is entitled to be raja. There are also some 'regular negeri' that cannot be categorized as 'customary negeri,' such as Loki, Ani, Olas and Katapang, where the villages were originally the concession area of PT Panca Karya before being occupied by newcomers and turned into a negeri. The government is still trying to accommodate this difference in a regulation that can cover both types of negeri.

\footnotetext{
${ }^{10}$ Some learning materials from Kewang Haruku to 'Kewang kecil' are the importance of preserving lompa fish and marine ecosystems through the sasi mechanism, cleaning the coast and planting mangrove seedlings around the location of the lompa sasi (Learisa Kayeli river). The result of this learning is increasing Haruku children awareness on the importance of preserving the coastal and marine environment which has a direct impact on the implementation of conservation practices based on traditional Haruku conservation system that are sustainable and have a positive impact on the environment, economy and socio-culture (Baileo Foundation Document, 2018).
} 
The uncertainty of the legal umbrella due to the prolonged Negeri Government ultimately affects the governance dynamics of customary negeri, especially in determining its raja leadership based on mata rumah parentah tradition. As a consequence, the district head took over the authority of the adat community by appointing a temporary village head from district government staff, while waiting for the customary negeri regulation to be officially issued by local parrliament of the presiding West Seram District. ${ }^{11}$ Therefore, at present the governance of custmmary negeri is under the political control of the District Head. ${ }^{12}$

Kewang in Haruku is relatively intact and widely known outside Maluku, while the kewang in South Buano has just been reactivated after more than three decades of a customary vacuum. In fact, almost all traditional instruments or organizations are stagnating in Buano. The recent interest to soa and kewang only emerge after the LPPM started to work in this negeri. Moreover, the local government has not paid serious attention at strengthening the capacity of customary institutions and organizations. Revitalizing institutions has been a challenge for LPPM in South Buano customary organizations, as local leadership and village government had long ignored the quality of knowledge about customary institutions and organizations in the community. This institutional memory is particularly absent among the younger generation. Therefore, the role and function of adat organizations are weakening its absence is not viewed as a priority issue to be resolved. ${ }^{13}$

The decline of customary institutions and organizations is contrary to the changes identified in prevailing national village legislation and the recognition of indigenous peoples. As a remote area with relatively difficult and time-consuming transportation access, the people in Buano Island are not aware of recent information and programs to empower indigenous peoples. The Village Law mandates each negeri (customary village) to prepare a document of genealogical origin, articulating the customary rules of the community and mapping its boundaries. In these regions, such efforts have been piecemeal or take its cues from othe administrative examples.. Even the Ministry of Home Affairs Regulation No. 52/2014 on Guidelines for the Recognition \& Protection of Indigenous Peoples states the requirements for recognition of indigenous peoples, which can take place if the negeri has: a history of origin, customary territories, customary law, customary assets, and governmental systems. But this process had not been followed until the arrival of LPPM Maluku, which helped South Buano to articulate themselves as indigenous people in order to mmake the case for proposals on empowerment programs from both the government and non-government organizations.

The presence of LPPM Maluku in South Buano and North Buano for the revitalization of indigenous peoples for about four years has generated a number of changes. First, the community began by researching Buano customary institutions, both from the aspect of worldviews and norms, values and knowledge of indigenous peoples related to the environment and various types of prohibitions known in natural resource management. Secondly, customary instruments such as bapa raja, heads of soas and datis began to hold regular meetings, not just to discuss the programs

\footnotetext{
11 Interview with Adam Latupono, civil servant of Seram Barat District, July 2019

12 This practice is referred to by a political scholar in Ambon as 'adat politicization'. One of the practices of adat politicization is the establishment of a 'Latupati of Maluku' or an alliance of rajas in Maluku. In fact, the existed traditional institutions are only the allies of rajas in one island, for example, Latupati of Haruku Island, Latupati of Saparua Island, Latupati of Seram Island and so on. Latupati across Maluku and the inauguration of the Latupati chairman is only a way to intervene in the prevailing adat system in the islands. Politicians, in carrying out the practice of custom politicization, gather Latupati from each island and prepare an office in Ambon City. For Eliza, the meeting of the rajas of the islands (Latupati) in an office prepared by the local government would only make it easier for politicians to embed their vested their interests.

${ }_{13}$ LPPM Maluku through the "Revitalizing Local Wisdom for Sustainable Management of Natural Resources" program, supported by the Burung Indonesia and the Critical Ecosystem Partnership Fund has five components of activities in Buano Island such as: strengthening adat institutions and organizations; participatory mapping of Buano Island Natural Resources; community-based DPL establishment and strengthening; support of sustainable livelihoods in natural resource management; education and care for the environment.
} 
with the LPPM Maluku, but also to convene the 'saniri,' the traditional consultation forums. The forum involves more than just electing heads of soas as traditional cultural practitioners, but also discusses public affairs, such as preparing a mapping plan for the petuanan areas. Third, the process of integrating soa and kewang instruments and their functions into the government system, both in terms of the interests of government management and budgeting, have since begun.

However, without a definitive head of negeri the institutionalization of adat into formal regulations has faltered. This political situation has weakened the power of efforots to revitalize local customary institutions and reassert their role in managing natural resouorces. Thus, LPPM Maluku's main agenda has been to help reinstate the instruments for empowering indigenous peoples in the re-establishment of kewang and its institutionalization into the formal governance structures.

In South Buano, the appointment of eight kewang members by the heads of soa is now waiting for the official Establishment Decree by the raja or the definitive head of negeri. Although the decree has not been issued, the existence of new kewang has been recognized by the heads of soas and the temporary head of the Negeri, allocating budgets for operationalization of kewang functions. The kewang structure in South Buano adopted a modern organization structure with a Head, Secretary, and Treasurer. Without the revival of the cultural foundations however, the formal establishment of the kewang is more transactional, shaped by profit and loss calculations between individual kewang members.

In contrast, in Haruku, the kewang initiatives continue to emerge both independently and with the organizing support of the Baileo Foundation. To protect and manage natural resources sustainably, the kewangs of Haruku have undertaken a number of activities with or without the support of their partners. The most intensive was the annual ritual of 'Buka Sasi Lompa' at the Learisa Kayeli river (usually takes place between October and December), which is a harvest feast and ritual to catch lompa fish as part of the sasi system. ${ }^{14}$

The leadership figure of Kewang Haruku Chief is significantly different from South Buano in terms of management of natural resources of the petuanan. The current leader, Eliza, is a highly experienced head of kewang who has participated in various non-formal education on the environment, community development and organization, community education methodology and media, and protection of the rights of local indigenous peoples. He is not only a local advocate but also is involved in national and regional efforts across Southeast Asia (in Malaysia, Thailand and the Philippines). He also attended a number of international forums in Europe (the Netherlands and Spain).

As the chief of kewang in Haruku, Eliza Kissya continues to enforce the traditional law and norms based on local customs in protecting the environment. In addition, he also revised the sasi law to protect the population and habitat of lompa fish, turtles and Maluku Gosong birds and incorporated women in kewang membership. Such kewang related innovations are not only practiced by Eliza Kissya as the chief, but also by the members. For instance, a kewang member works to raise the Haruku youth awareness on the importance of maintaining and managing petuanan resources sustainably. Together with the next kewang chief candidate (Eliza Kisya's son) they organize a number of social activities especially before Christmas at the kewang house. Eliza Kissya's innovative efforts have earned him environmental awards at national and international levels.

Kewang of Haruku also still relies on traditional decisionmaking mechanisms. Only sasi rule violations that cannot be resolved at the kewang will be submitted to the soa and raja or even to

\footnotetext{
14 In addition to sasi lompa, kewang of Haruku also applies the sasi laut (to protect the marine biodiversity of the coastal areas), sasi sungai (to maintain cleanliness and livelihoods of the springs and rivers that divide the village), and the sasi negeri (to maintain harmony between between the villagers and surrounding environment within the village). The whole system is called 'Sasi Aman Harun'ukui' (Aman = village/negeri).
} 
the Latu-Pati forum, i.e. conflict resolution between two villages in one island. Until now, every Friday, the kewang holds regular meetings to discuss the results of protection by its members, discusses any violations by identifying suspected violations and runs kewang court if the violation provisions are met.

Eliza's extensive engagement on environmental and indigenous peoples' issues led him to contribute to the establishment of organizations and networks such as the Maluku Baileo Network, and the Alliance of Indigenous Peoples of the Archipelago (AMAN). Eliza also revived the pantun (rhymed verse) tradition by creating new songs based on his life experiences, in addition to the ancestral verses. Today the pantun he created has been adopted by the local elementary schools as part of their curriculum.

Considering the role of kewang chief as a cultural duty established for centuries by his ancestors, Eliza Kissya still strives to meet the needs of his family by cultivating cloves, cassava, and various vegetables. He also developed organic farming, alternative energy, and cultural tourism in his negeri. Other kewang members also applied similar livelihood strategies to make ends meet while still carrying out their conservation roles.

In South Buano, kewang is still under development through the support of LPPM and partners from various parties, including universities and government. They participated in some technical trainings on sustainable natural resources protection and management, such as mapping natural resources and petuanan zones in Buano Island, monitoring forestry resources, planting mangroves in hamlets, managing plants using permaculture models, exploring local values and knowledge, strengthening the capacity of customary instruments and mainstreaming local values and cultures. All these efforts aim to strengthen the understanding of rules, norms and values of customary institutions.

So far, the LPPM program managed to facilitate the kewang to carry out protection functions. Together with other indigenous organizations, the kewang of South Buano mapped the indigenous territories-while breaking the old tradition that forbids the people of physically pointing (with fingers) the boundaries of the region. In addition, the kewang monthly meeting has been initiated where they meet with the negeri government and discuss the kewang operation guidelines which will be the basis of village government to issue a decree.

The kewangs performed the protection and patrol roles in conjunction with their daily activities, such as fishing, farming or eucalyptus oil processing. They warn violators they will report them to the head of the soa and raja. The most common violations are related to natural resources use and logging permits.

\subsection{Bargaining power}

Kewang has a very strong political position in Haruku. Under Eliza Kissya's leadership, this organization won a large material and symbolic conflict against a large multinational mining initiative in the 1990s and managed to stop exploration plans for geothermal and gold in 2006 led by a team from the Ministry of Energy and Mineral Resources. The Kewang of Haruku is widely known for maintaining the tradition of sasi lompa attracting thousands of visitors from beyond Haruku Island annually. ${ }^{15}$ In addition, Kewang Haruku also has a wide network of community organizations in Maluku and advocates at the national level through AMAN, as well as the national governments such as the Ministry of Maritime Affairs. In addition, within the negeri, kewang is part of the soa and not subordinate to the raja. The tabaos process or the dissemination of sasi provisions are regularly delivered to all people of the negeri and serves as warning against exploitation of resources. All local and neighboring comunities are assumed to know the rules and every soa have at least eight members of kewang serving the respective petuanan. As locally

\footnotetext{
${ }^{15}$ Indicated by the number of speedboat operations during the ritual period (more than 500 trips).
} 
described "forest and marine rangers," kewang deals with various parties interested in the utilization of natural resources and environment of Haruku on the land, river, or ocean.

In South Buano, the reactivation of the kewang after a more than three deccades long hiatus was difficult as it continues to remind community members, especially women, of the traumatic and bloody conflicts with North Buano in 1983. The cultural legitimacy of the re-establishment of kewang and the election of 8 members is still weak, though their capacity has been facilitated by efforrts from LPPM Maluku through some trainings and practices on environmental protection. Unfortunately, although increasingly gaining formal legitimacy, for some people, the weaknesses oof kewang authority are in the adoption of a 'rationalist' perspective in calculating 'profit and loss,' rather than considering their roles as a foormm $\mathrm{f}$ cultural authority as observed in Haruku.

For the kewang of Buano, a decree provides the authority to carry out protection functions, legitimized by negeri regulation and included in the village budgeting system. Therefore, they are entitled to a monthly incentive and can secure equipment and tools to support their roles. The profit and loss calculation emerged as part of the workload assigned to a kewang as compared to other village-based organizations such as the head of soa, who were in charge for simpler tasks and received greater incentives. The task of the kewang is to deal directly with vilators such as bomb fishing, while the head of soa only addresses offenders already captured.

The material calculations however made the South Buano kewang's political bargaining power weaker than the one in Haruku. With the position of membership originating from the chosen clan and the education of a kewang who had started since childhood, resulted in the kewang of Haruku to be perceived as having a deep and embedded structure withinn local values adhered to by the people of Haruku. The more kewang members perform their roles as guardians and protector of the petuanan, the stronger their political position in banning and sanctioning violators.

\section{Discussion}

Overall, the strengthening of church and state ideologies weakens traditional customary ideologies that underlie endogenous institutions. In Haruku, the ideological battle takes place more openly because customary ideology is still firmly rooted and still has direrct functions in the community. Meanwhile in South Buano, the customary ideology has been dormant for a long time and is in the process of being slowly forgotten and selectively remembered. This allows the church and state ideologies to weaken and further subordinate customary institutions, including the underlying ideology behind kewang in South Buano, even amidst kewang revitalization established based on custommary-based ideology.

Violent conflict instigated a longstanding vacuum of cultural institutions on natural resource management, and political influence at the district level resulted in the South Buano community unclear about the authority of re-establishing their endogenous institutions. In this case, they were assisted by an external entity, LPPM Maluku, to rebuild what they had left behind due to the conflict. This is in sharp contrast with the case of Haruku, whereby local state agencies and the church, as well as local community members respect the kewang.

The fact that kewang is still shaping meaningfull resource management functions in Haruku grants them a strong bargaining position, and the majority of Haruku people obey the rules. This can be observed in the application of sasi lompa that requires all community members not to harvest the lompa fish before the prescribed period, i.e. before the kewang lift the prohibition. Meanwhile, in South Buano, with the re-establishment of kewang initiated by an external actor, and receiving financial support from state institutions, their bargaining position remains relatively weak. Similarly, the politically motivated delay of issuing district regulation on the negeri government meant that traditional customary organizations cannot fully regain decisionmaking authority at the negeri level. This condition creates an awkward situation where the membership of kewang as a traditional organization is ruled by a rational choice ideology negotiated by state administrative functions and 
budgets, prioritized relative to the calculation of profit and loss in carrying out their tasks. Unless they view such a role within the broader framework of the cultural legitimacy of kewang, it is unsurprising that they quantify their involvement in the kewang under transactional terms.

Such institutions no doubt have impacts on the ecological conditions in both places. In South Buano, the long vacuum oof a kewang was followed by the widespread degradation of land and coastal resources. The destructive fishing practices on the reefs were particularly widespread. The exploitation of Buano forests also took place due to high demand of timber for boat materials. Nevetheless revival ofo the kewang has not been without its conservation benefits. The decline of fish bombing practices only began since LPPM Maluku began working in Buano island and helping to re-establish kewang. In Haruku, rules on resuorce use did not undergo similar disruptions; and combined with successful contestation against large mining interests, kewang have also since developed programs for habitat and endangered species conservation.

\section{Conclusion}

Institutions in a community influence individuals on protecting a resource, and we have shown the conditions and path dependence in two negeri in Maluku. Livelihoods, particularly in rural and frontier regions, play a central role, but the cases of Haruku and South Buano show the various conditions that either help conservation outcomes or undermine them. The absence of kewang over a long period points to the pathways that available institutions can play and continue to play governing the behavior of the individuals. Moments of victory against mining corporation enclosures (Haruku) or the effects of a conflict and violence (South Buano) have long term consequences on how local cultural norms are practiced, and certainly affect the possibilities for conservation and natural resource management generations hence.

In addition, the strength or weakness of kewang in South Buano and Haruku in conservation and management of petuanan resources depends on the support of all institutions and organizations related to sasi and petuanan in one negeri. We have shown how in both situations the formal institutions interact closely with Kewang to shape new forms of legitimacy. In South Buano, new efforts at revitalizing kewang are still capable of performing key roles in natural resource management. Unfortunately, at this early juncture, South Buano still suffers from two key challenges. The first is that the kewanng has limited legitimacy as it is seen as a transactional organization, and the generational loss of identity among the youth to relate to the kewang as they do in Maluku means it is less effective at influencing local practices. The second key point is that the formal government channels have also created uncertainty about the legitimacy of local institutions due to the unwillingness of the district to allow local elections to take place.

All institutional constellations need to work effectively to guarantee the sustainability and effectiveness of kewang if it is to function as a credible institution in natural resource management. Across longer temporal scales, a variety of external factors affected community institutions in Maluku. Some traditional institutions and indigenous organizations can adapt, be erased, or revived. They have been through different paths in histories, though they may be located geographically close to one another. Nevertheless, we have shown that this does not change the possibilities for shaping new futures.

\section{Acknowledgments}

The research was supported by the Critical Ecosystem Partnership Fund (CEPF) through Burung Indonesia. However, this paper solely represents the view of the researchers, and not necessarily those of CEPF. The authors like to thank the two anonymous reviewers for their useful and insightful comments to the first version of this paper. 
Conflicts of interest

The authors declare no conflict of interest.

\section{References}

Abrahamsz. J et.al. (2018). Survai Ekologi Sumberdaya Pesisir dan Laut Negeri Haruku dan Sameth (Coastal and Marine Resource Ecological Survey of Haruku and Sameth Villages), Yayasan Baileo Maluku - Burung Indonesia (Critical Ecosystem Partnership Fund)

Abrahamsz, J. (2012). Model Dinamika Spasial Sistem Perikanan: Kasus Pengembangan Kawasan Perikanan Pelagis Kecil di Kabupaten Maluku Tengah (Spatial Dynamics Model of Fisheries System: A Case for the Development of Small Pelagic Fisheries Areas in Central Maluku Distric). Dissertation. Institut Pertanian Bogor. p.375.

Abrahamsz, J., F. W. Ayal., and Y. Lopulalan. (2015). Inventarisasi dan Identifikasi Calon Kawasan Konservasi Perairan, Pesisir dan Pulau-Pulau Kecil pada Gugus Pulau VII Provinsi Maluku (Inventory and Identification of Prospective Waters, Coastal and Small Islands Conservation Areas in Group of Islands VII of Maluku Province). Collaboration with the Maluku Provincial Maritime and Fisheries Office. p.92.

Abrahamsz, J., F. W. Ayal., and Y. Lopulalan. (2017). Identification and Inventory of Coastal and Small Islands Conservation Area in the Lease Islands, Maluku Province. Occasional Papers, No. 58: 37-43. Kagoshima University Research Center for the Pacific Islands. ISSN: 1345-0441. (March, 2017).

Al Qurtuby, S. (2016). Religious violence and conciliation in Indonesia: Christians and Muslims in the Moluccas: Abingdon, UK, Routledge.

Benda-Beckmann von, F., K. von Benda-Beckmann and A. Brouwer. (1995). Changing "Indigenous Environmental Law" in the Central Moluccas: Communal Regulation and Privatization of Sasi. In Ekonesia. A journal of Indonesian Human Ecology. No. 2, p. 1-38. Program Studi Antropologi-Program Pascasarjana. University of Indonesia.

Cultural Research team of Maluku Province. (1976). Sejarah Daerah Maluku (The History of Maluku), The Ministry of education and culture, center for historical and cultural research.

Ensminger, J. (1992). Making a Market. The Institutional Transformation of an African Society. Cambridge University Press.

Ensminger, J. (1998). Anthropology and the New Institutionalism. Journal of Institutional and Theoretical Economics (JITE) / Zeitschrift Für Die Gesamte Staatswissenschaft, 154(4), 774789. Retrieved April 6, 2020, from www.jstor.org/stable/40752112

Froger, G., \& Méral, P. (2012). Towards an institutional and historical analysis of environmental policy in Madagascar. Environmental Policy and Governance, 22(5), 369-380. doi: https://doi.org/10.1002/eet.1595

Goodin, R. E. (2000). Institutional gaming. Governance, 13(4), 523-533. doi:https://doi.org/10.1111/0952-1895.00144

Haller T. (2007). Understanding Institutions and Their Links to Resource Management from the Perspective of New Institutionalism. 2nd edition [20021]. NCCR North-South Dialogue 2. Bern, Switzerland: NCCR North-South. Retrieved April 6, 2020, from https://boris.unibe.ch/52831/1/Haller_NCCR_Dialogue_2.pdf

Novaczek, I., Harkes, I.H.T., Sopacua, J., and Tatuhey. M.D.D. (2001). An Institutional Analysis of Sasi Laut in Maluku, Indonesia. ICLARM Tech. Rep. 59, 327 p.

Khan, B., Lazuardi, M. E., Tamher. A., dan Leithenu, F. J. (2016). Rapid Ecological Assessment (RAE) of Sea Mammals in the Banda and Seram Seas: Preliminary Summary and Management Implications. Presentation. APEX Evironmental. 48 pp.

Kissya, E., 2013. Kapata Kewang Haruku Dan Tradisi sasi Aman Haru-Ukui (Sasi Aman Haru-ukui: Traditional Management of Sustainable Natural Resources in Haruku). Makassar: Ininnawa 
dan Layarnusa.

Soselisa, H. L. (2000). Sagu Salempeng Tapata Dua: Conflict and Resource Management in Central Maluku. Cakalele, 11, 67-82.

Zakaria, R. Y. (2000). Abih Tandeh, Masyarakat Desa di Bawah Rejim Orde Baru. Jakarta: ELSAM

The Law No. 5/1979 on Village Governance

The Law No. 27/2007 on Management of Coastal Areas and Small Islands.

The Law No. 1/2014 on Amendment of Law No. 27/2007 on Management of Coastal Areas and Small Islands.

The Regulation of the Ministry of Maritime and Fishery No. 17/2008 on Conservation Areas in Coastal Areas and Small Islands

The Ministry of Home Affairs Regulation No. 02/2009 on The Procedure for Establishing a Water Conservation Area.

The Regulation of the Ministry of Maritime and Fishery No.30/2010 on Zoning Management Plan and Conservation Water Areas.

The Ministry of Home Affairs Regulation No. 52/2014 on Guidelines for the Recognition \& Protection of Indigenous Peoples 